\title{
Evaluasi Legalitas Dan Kelengkapan Administratif Resep Pada Rumah Sakit di Kabupaten Brebes
}

\author{
Hanari Fajarini*1, Atrian Widodo ${ }^{2}$ \\ ${ }^{1,2}$ Program Studi D3 Farmasi Fakultas Ilmu Kesehatan Universitas Muhadi Setiabudi \\ Jl. P. Diponegoro KM 2 Kabupaten Brebes, Jawa Tengah \\ e-mail: *1 hanari.fajarini@gmail.com
}

Article Info

Article history:

Submission Mei 2020

Accepted Juni 2020

Publish Juli 2020

\begin{abstract}
Abstrak
Penelaahan Penelaahan legalitas dan kelengkapan administratif dalam resep dapat mengurangi atau bahkan mencegah terjadinya kesalahan pengobatan atau medication errors, yaitu kejadian yang dapat mengakibatkan kerugian kepada pasien akibat dari pemakaian obat yang kurang tepat selama dalam penanganan tenaga kesehatan. Penelitian ini bertujuan untuk mengevaluasi kelengkapan administratif resep yang merupakan aspek legal dari suatu resep, dengan mengkaji kemungkinan terjadinya kesalahan pengobatan dari dokter penulis resep. Penelitian ini merupakan penelitian kualitatif dengan menggunakan metode analisis data deskriptif, pengambilan sampel dilakukan secara snowball method. Terdapat 267 lembar resep yang diteliti selama periode dari tanggal 7, 8, 9, 10, 11, 14 dan 15 Agustus 2017 kemudian dievaluasi kelengkapan administratifnya. Kelengkapan administratif resep yang dituliskan oleh dokter pada resep, yakni nama pasien (100\%), jenis kelamin (100\%), umur pasien (0\%), alamat pasien (98.8\%), nama dokter (97.1\%), nomor Surat Ijin Praktek dokter (42.3\%), alamat dokter (0\%), paraf dokter (0\%), tanggal peresepan (95.8\%), berat badan pasien (0\%). Dari data yang diperoleh, sebagian besar resep telah memenuhi kriteria legalitas dan kelengkapan administratif resep sebagaimana termuat dalam Peraturan Menteri Kesehatan Republik Indonesia Nomor 72 Tahun 2016 Tentang Standar Pelayanan Kefarmasian di Rumah Sakit.
\end{abstract}

Kata kunci-legalitas, administratif resep, kesalahan pengobatan

\begin{abstract}
Review of legal aspect and completeness of prescribing administration can reduce or eliminate medication errors, that is incidents adverse patient due to the use of drugs during the handling of health personnel. This study is intended for completeness surgery by examining the possibility of treatment of errors from internist at Bakhti Asih Hospital. This research is descriptive conducted in snowball method to the patient's prescription. There are 267 recipes available internist Bhakti Asih Hospital during the period from 7th, 8th, 9th, 10th, 11th, 14th and 15th of August 2017 then evaluated its administrative completeness. Completeness of prescriptions administration written by internistat as patient name (100\%), gender (100\%), patient age (0\%) patient address (98.8\%), doctor's name (97.1\%), doctor's address (0\%), signature doctor's (0\%). prescribing date $(95.8 \%)$, height Patient (0\%), doktor's license numbers (42.3\%) from these data it can be concluded that the potential for medication error and none of the recipes that meet the prescription screening criteria in the administrative completeness of prescriptions is based on the Regulation of the Minister of Health of the Republic of Indonesia Number 72 of 2016 about Pharmaceutical Services Standards in Hospitals.
\end{abstract}


Keyword - legal aspect, prescription administration, medication error

DOI 10.30591/pjif.v\%vi\%i.1969

C2020PoliteknikHarapanBersamaTegal

\begin{tabular}{lr}
\hline Alamat korespondensi: & \\
Prodi DIII Farmasi Politeknik Harapan Bersama Tegal & \\
Gedung A Lt.3. Kampus 1 & \\
Jl. Mataram No.09 Kota Tegal, Kodepos 52122 & p-ISSN: 2089-5313 \\
Telp. (0283) 352000 & e-ISSN: 2549-5062 \\
E-mail: parapemikir_poltek@yahoo.com &
\end{tabular}




\section{A. Pendahuluan}

Pengertian resep menurut Permenkes RI Nomor 72 Tahun 2016 tentang Standar Pelayanan Kefarmasian di Rumah Sakit, resep adalah permintaan tertulis dari dokter atau dokter gigi, kepada apoteker, baik dalam bentuk paper maupun electronic untuk menyediakan dan menyerahkan obat bagi pasien sesuai dengan peraturan yang berlaku.

Resep yang baik harus memuat cukup informasi yang memungkinkan apoteker atau tenaga teknis kefarmasian dapat mengerti dan memahami obat yang akan diserahkan kepada pasien. Pada kenyataanya, permasalahan peresepan masih banyak dijumpai. Beberapa contoh permasalahan dalam peresepan diantaranya kurang lengkapnya penulisan data/informasi tentang pasien, tulisan dalam resep yang kurang jelas atau tidak terbaca, ketidaktepatan dalam penulisan dosis,tidak dicantumkannya aturan pakai obat, tidak adanya rute pemakaian obat serta tidak terdapatnya tanda tangan atau paraf dokter pada resep. Terdapat sejumlah faktor yang dapat mempengaruhi terjadinya permasalahan dalam penulisan resep, sehingga dibutuhkan kepatuhan dokter dalam penulisan resep sesuai dengan peraturan perundang-undangan yang berlaku ${ }^{[1]}$.

Permasalahan dalam peresepan merupakan salah satu faktor pemicu terjadinya kesalahan pengobatan atau medication error, yaitu kejadian yang dapat merugikan pasien akibat dari pemakaian obat dalam penanganan tenaga kesehatan yang sebetulnya dapat dicegah [2]. Bentuk kesalahan pengobatan atau medication error yang terjadi pada fase prescribing atau terjadi pada saat penulisan resep yaitu kesalahan yang dapat terjadi selama proses penulisan resep. Dampak dari kesalahan pada fase prescribing ini sangat beragam, mulai dari tidak ada resiko sama sekali hingga mengakibatkan timbulnya kecacatan atau bahkan kematian. Selain itu medication error dapat menimbulkan kegagalan terapi, bahkan dapat mengakibatkan terjadinya efek obat yang tidak diinginkan seperti terjadinya interaksi obat [2]. Meskipun kesalahan pengobatan terkadang serius, akan tetapi sering kali luput dari perhatian. Sangat penting untuk mendeteksinya dari awal, karena kegagalan sistem pengobatan yang awalnya berupa kesalahan kecil dapat menyebabkan kesalahan serius di kemudian hari ${ }^{[3]}$. Oleh karena itu tujuan penelitian ini adalah untuk mengevaluasi legalitas dan kelengkapan administratif resep pada salah satu rumah sakit yang menjadi sampel dalam penelitian ini, dengan harapan hasil penelitian ini dapat dijadikan masukan dalam hal peresepan, sehingga dapat mendukung upaya peningkatan mutu pelayanan pasien.

\section{B. Metode}

Metode penelitian yang digunakan dalam penelitian ini adalah metode penelitian kualitatif. Metode penelitian kualitatif merupakan prosedur dalam penelitian yang menghasilkan data deskriptif yang berupa kata-kata tertulis atau lisan dari manusia dan perilakunya yang dapat diamati, untuk menggambarkan secara jelas mengenai masalah-masalah yang diteliti serta menjelaskan proses dan evaluasi suatu kegiatan yang sedang diteliti apakah sesuai pedoman ${ }^{[4]}$. Pengambilan data dilakukan secara snowball method yaitu metode pengambilan sampel atau sampling dimana sampel didapat melalui proses bergulir seperti bola salju dari satu informan ke informan yang lainya ${ }^{[5]}$. Analisis data menggunakan metode deskriptif analisis yaitu suatu metode yang digunakan untuk mendapatkan gambaran secara nyata atau faktual dan juga akurat berkenaan dengan fakta-fakta yang ada di lapangan, sifat- sifat serta hubungan antara fenomena yang sedang diteliti ${ }^{[6]}$. Dalam penelitian ini, yang menjadi instrumen utama adalah peneliti itu sendiri ${ }^{[6]}$. Adapun intrumen pendukung yaitu resep, catatan lapangan, buku catatan, kamera, wawancara dan ballpoint.

\section{Hasil Dan Pembahasan}

Dari hasil penelitian yang telah dilakukan, diketahui bahwa resep yang diteliti dari tanggal 7, 8, 9, 10, 11, 14 dan 15 tahun 2017 berjumlah 267 lembar resep. Dengan jumlah resep terbanyak pada tanggal 7 agustus 2017 yaitu sejumlah 53 resep dan dengan jumlah resep yang paling sedikit pada tanggal 14 agustus 2017 yakni sejumlah 23 resep.

Berdasarkan data yang diperoleh, diketahui bahwa rata-rata resep per hari adalah 38 resep. Jumlah resep secara terperinci dapat dilihat di setiap harinya pada Tabel 1 .

Tabel 1. Jumlah resep pada Rumah Sakit di Kabupaten Brebes.

\begin{tabular}{|c|c|c|c|c|c|c|c|}
\hline Tgl & $7 / 8 /$ & $8 / 8 /$ & $9 / 8 /$ & $10 / 8$ & $11 / 8$ & $14 / 8$ & $15 / 8 /$ \\
& 17 & 17 & 17 & $/ 17$ & $/ 17$ & $/ 17$ & 17 \\
\hline
\end{tabular}


\begin{tabular}{|l|l|l|l|l|l|l|l|} 
Jml & 53 & 42 & 33 & 51 & 41 & 23 & 24 \\
\hline
\end{tabular}

Total 267 resep dari dokter spesialis penyakit dalam

Dari data yang didapat dari penelitian, diketahui bahwa jumlah keseluruhan resep pada tanggal $7,8,9,10,11,14$ dan 15 adalah berbeda-beda setiap harinya.

Dalam penelitian ini resep yang diteliti dimulai dari tanggal 7, 8, 9, 10, 11, 14 dan 15 Agustus 2017. Evaluasi dilakukan dengan menilai sendiri berdasarkan Peraturan Menteri Kesehatan Republik Indonesia Nomor 72 Tahun 2016 Tentang Standar Pelayanan Kefarmasian di Rumah Sakit.

Skrining resep merupakan suatu pemeriksaan dari resep yang dilaksanakan oleh apoteker maupun petugas apotek setelah resep diterima. ${ }^{[7]}$ Penelitian yang dilakukan pada salah satu Rumah Sakit di Kabupaten Brebes, yaitu dengan melakukan evaluasi terhadap kelengkapan administratif resep sebagai bentuk legalitas dari suatu resep sebagaimana diatur dalam Peraturan Menteri Kesehatan Republik Indonesia Nomor 72 Tahun 2016 Tentang Standar Pelayanan Kefarmasian di Rumah Sakit. Evaluasi yang dilakukan berupa telaah berkenaan dengan ada tidaknya nama dokter penulis resep, nomor Surat Ijin Praktek atau SIP dokter penulis resep, alamat praktek dokter, paraf dokter, tanggal penulisan resep, nama pasien, berat badan dari pasien (BB), tinggi badan pasien (TB), jenis kelamin, alamat pasien dan umur pasien.

Berdasar hasil evaluasi kelengkapan administratif resep pada nama pasien yang sudah dituliskan oleh dokter spesialis penyakit dalam telah mencapai $100 \%$. Dalam hal ini, dokter telah berperan dengan baik dalam upaya penyembuhan pasien sehingga dapat mengurangi bahkan meniadakan potensi terjadinya medication error.

Surat Ijin Praktek atau SIP merupakan pengakuan legal formal bagi seorang dokter untuk menjalankan praktek profesinya. Penulisan nomor SIP menjadi penting dalam resep guna memberi kepastian hukum bagi dokter dan pasien, melindungi profesi dokter serta menjamin keamanan dan keselamatan pasien. SIP juga merupakan pengakuan bagi dokter bahwa ia berhak dan dilindungi oleh undang-undang dalam memberikan pengobatan kepada pasien. Namun pada kenyataanya dari resep yang diteliti masih ada sebagian dokter spesialis penyakit dalam pada yang tidak mencantumkan Nomor Surat Ijin Praktek dokter yakni $57.7 \%$, dan yang sudah mencantumkan ada $42.3 \%$, padahal Surat Ijin Praktek (SIP) adalah salah satu persyaratan menulis resep yang harus dicantumkan sebagaimana tertuang dalam Peraturan Menteri Kesehatan Republik Indonesia Nomor 72 Tahun 2016 Tentang Standar Pelayanan Kefarmasian di Rumah Sakit.

Keberadaan tanggal penulisan resep sangat dibutuhkan karena berkaitan dengan keamanan dan keselamatan pasien. Selain itu fungsi dari penulisan tanggal pada resep dapat menghindarkan petugas kefarmasian ambigu dalam membaca resep. Dari data hasil penelitian diketahui bahwa belum semuanya Dokter Spesialis Penyakit Dalam menuliskan tanggal penulisan resep. Terdapat $4.2 \%$ dari resep yang diteliti belum mencantumkan tanggal peresepan dan ada $95.8 \%$ dari resep. Persentase kepatuhan dokter dalam penulisan tanggal resep terbilang tinggi, ini menunjukan kepatuhan hukum yang sudah baik dilihat dari segi pencantuman tanggal peresepan, budaya hukum yang terbangun sudah mulai konstuktif. Pada saat resep pertama kali di terima oleh apoteker ataupun petugas kefarmasian lainnya yang harus dilakukan adalah melaksanakan skrining resep. Skrining resep merupakan kegiatan pemeriksaan mengenai kelengkapan administratif resep, dan apabila terdapat kekurangan penulisan tanggal dalam resep dapat ditambahkan oleh atau petugas di instalasi farmasi atau apotek. Penulisan tanggal peresepan adalah salah satu persyaratan menulis resep yang harus ditulis sesuai dengan Peraturan Menteri Kesehatan Republik Indonesia Nomor 72 Tahun 2016 Tentang Standar Pelayanan Kefarmasian di Rumah Sakit.

Penulisan jenis kelamin pada resep merupakan salah satu aspek yang sangat penting dan dibutuhkan untuk merencanakan atau menentukan dosis obat dalam pengobatan pasien. Dari hasil penelitian dokter sudah menuliskan $100 \%$ jenis kelamin dalam resep. Dalam hal ini budaya hukum dokter sudah sangat konstruktif dan dokter memiliki peran yang sangat baik dalam upaya penyembuhan pasien sehingga dapat meminimalisasi potensi untuk terjadinya medication error.

Berat badan pasien juga merupakan salah satu aspek yang diperlukan dalam perhitungan dosis. Dalam penentuan dosis para ahli telah 
membuat rumus khusus berdasarkan berat badan seseorang, untuk itu berat badan pasien sangat perlu dicantumkan dalam penulisan resep. Dari data hasil penelitian tidak ditemukan resep yang mencantumkan berat badan pasien. Berat badan pasien harus selalu ada dalam penulisan resep, sesuai di dalam Peraturan Menteri Kesehatan Republik Indonesia Nomor 72 Tahun 2016 Tentang Standar Pelayanan Kefarmasian di Rumah Sakit, bahwa berat badan pasien termasuk salah satu persyaratan penulisan administratif resep.

Paraf dokter juga merupakan salah satu aspek yang perlu dicantumkan di dalam penulisan resep untuk menghindari penyalahgunaan dan untuk memastikan keaslian resep bahwa dokter yang bersangkutan benar membuat resep. Namun dari hasil penilitian ini tidak ditemukan resep dari dokter spesialis penyakit dalam yang menuliskan paraf dokter. Paraf dokter harus ditulis dalam penulisan resep sesuai di dalam Peraturan Menteri Kesehatan Republik Indonesia Nomor 72 Tahun 2016 Tentang Standar Pelayanan Kefarmasian di Rumah Sakit, bahwa paraf dokter termasuk salah satu persyaratan penulisan administratif resep.

Penulisan umur dalam resep sangat diperlukan sehingga para ahli telah membuat rumus-rumus khusus untuk penentuan dalam dosis anak. Rumus Young, Dilling dan Fried merupakan rumus untuk menemukan dosis anak dalam usia tahun atau dalam usia bulan sehingga memudahkan dokter untuk menentukan dosis obat pasien anak. Namun dari data hasil penelitian tidak ditemukan resep yang memuat umur pasien, padahal umur dalam penulisan resep sangat diperlukan untuk menentukan dosis yang diberikan sudah sesuai atau belum. Umur juga merupakan salah satu syarat yang harus selalu ditulis di dalam penulisan resep, sesuai di dalam Peraturan Menteri Kesehatan Republik Indonesia Nomor 72 Tahun 2016 Tentang Standar Pelayanan Kefarmasian di Rumah Sakit.

Nama dokter juga merupakan salah satu aspek yang perlu dicantumkan di dalam penulisan resep untuk menghindari penyalahgunaan dan untuk memastikan keaslian resep bahwa dokter yang bersangkutan benar membuat resep, dan nama dokter juga diperlukan untuk mempermudah pasien atau tenaga kesehatan lainya dalam mencari informasi jika resep tidak jelas. Namun pada kenyataanya dari resep yang diteliti masih ada dokter yang tidak mencantumkan nama dokter yakni ada $2.9 \%$ dari resep yang diteliti, dan sudah mencapai $97.1 \%$ dari resep yang diteliti sudah mencantumkan nama dokter. Padahal nama dokter harus selalu ditulis dalam penulisan resep sesuai di dalam Peraturan Menteri Kesehatan Republik Indonesia Nomor 72 Tahun 2016 Tentang Standar Pelayanan Kefarmasian di Rumah Sakit, bahwa nama dokter termasuk salah satu persyaratan penulisan administratif resep.

Alamat pasien juga sangat diperlukan dalam penulisan resep di Rumah Sakit karena untuk memonitoring dan memastikan tidak terjadi kesalahpahaman pada nama pasien yang sama. Namun pada penelitian ini ada $1.2 \%$ dari resep yang diteliti tidak mencantumkan alamat pasien pada penulisan resep, dan sudah mencapai $98.8 \%$ dari resep yang diteliti sudah mencantumkan alamat pasien. Padahal alamat pasien harus selalu ada dalam penulisan resep, sesuai di dalam Peraturan Menteri Kesehatan Republik Indonesia Nomor 72 Tahun 2016 Tentang Standar Pelayanan Kefarmasian di Rumah Sakit, bahwa alamat pasien termasuk salah satu persyaratan penulisan administratif resep.

Alamat dokter juga merupakan salah satu aspek yang perlu dicantumkan di dalam penulisan resep untuk menghindari penyalahgunaan dan untuk memastikan keaslian resep bahwa dokter yang bersangkutan benar membuat resep, dan alamat dokter juga diperlukan untuk mempermudah pasien atau tenaga kesehatan lainya dalam mencari informasi jika resep tidak jelas. Pada penelitian kali ini alamat resep tidak dicantumkan mengingat dokter berpraktek di poliklinik rumah sakit. Sehingga alamat dokter mengikuti alamat rumah sakit yang tertera pada bagian atas resep atau kop resep.

Tinggi badan pasien juga diperlukan untuk memenuhi syarat dalam penulisan resep. Tetapi dari hasil penelitian tidak ditemukan resep dari dokter yang menuliskan tinggi badan pasien. Padahal tinggi badan pasien merupakan salah satu syarat dalam penulisan resep sesuai di dalam Peraturan Menteri Kesehatan Republik Indonesia Nomor 72 
Tahun 2016 Tentang Standar Pelayanan Kefarmasian di Rumah Sakit.

Dari hasil penelitian di atas masih menunjukan beberapa kekurangan dalam penulisan resep yang paling banyak tidak tertulis dalam resep seperti berat badan pasien, umur pasien, alamat dokter dan paraf dokter dengan prosentase mencapai $100 \%$. Menurut Apoteker yang bertugas di Apotek Rawat Jalan kekurangan dalam penulisan resep dikarenakan banyaknya pasien mengantri dan keterbatasan waktu sehingga dokter tidak sempat untuk menuliskan resep secara lengkap. Faktor yang menyebabkan terbatasnya waktu bisa datang dari pihak Rumah Sakit ataupun dari Faktor internal dokter. Faktor yang disebabkan dari pihak Rumah Sakit dikarenakan sejak datangnya era BPJS dan membuat jumlah pasien sangat meningkat drastis, jadi kurangnya efisien waktu, dan dokter kadang ingin cepat-cepat selesai. Dan penyebab terbatasnya waktu dari pihak dokter adalah karena biasanya ada dokter yang berpraktek di Rumah Sakit juga berpraktek di Rumah dan dengan melayani fasilitas BPJS, jadi dokter ingin bisa mengcover semua pasien yang datang di Poli Rumah Sakit ataupun pasien yang datang di Rumah. Jadi waktu sangat terbatas karena waktu dibagi menjadi dua dengan berpraktek di Rumah. Dalam hal ini faktor ekonomi mempengaruhi kepatuhan dan budaya hokum [8].

Untuk penulisan umur pasien tidak dicantumkan dalam resep karena dokter ketika pasien periksa langsung menanyakan ke pasien. Untuk penulisan alamat dokter tidak tercantum sama sekali, karena dokter berpraktek di rumah sakit sehingga hanya mencantumkan Surat Ijin Praktek (SIP). Pencantuman nama dokter di resep juga masih belum mencapai $100 \%$ masih terdapat $2,9 \%$ yang belum tertulis, menurut Apoteker yang bertugas hal ini dikarenakan dokter kadang menggantungkan pada perawat yang bertugas. Dan untuk penulisan berat badan pasien sama sekali tidak dicantumkan, menurut apoteker yang bertugas di tempat dikarenakan dokter biasanya hanya menuliskan berat badan pasien pada medical record. Biasanya sikap dokter yang seperti ini hanya terjadi pada dokter yang sudah senior bekerja sudah lama di Rumah Sakit, sedangkan dengan dokter yang masih baru biasanya masih memiliki sikap yang rajin dalam menuliskan kelengkapan administrasi resep. Dan dari pihak Rumah Sakit sudah mengadakan sosialisasi untuk menerapkan peraturan yang ada sesuai dengan undangundang yang berlaku.

Secara intrinksik, seseorang mematuhi suatu peraturan karena adanya proses internalisasi berdasarkan kepercayaan terhadap nilai-nilai dari yang bersangkutan. Adapun sebaliknya, seseorang akan cenderung apatis terhadap suatu peraturan karena nilainilai yang terkandung dalam peraturan belum terinternalisasi dalam diri seseorang, internalisasi nilai hanya akan didapat jika seseorang memhami isi yang dikandung oleh sutau peraturan. ${ }^{\left[{ }^{[9}\right.}$ Kepatuhan terhadap hukum atau peraturan-peraturan yang berlaku menyiratkan adanya kewibawaan hukum. Demikian pula sebaliknya, bahwa melemahnya wibawa hukum disebabkan antara lain oleh karena hukum tidak memperoleh dukungan yang semestinya dari kaidah-kaidah sosial lainnya. Di samping itu juga dapat dikarenakan oleh timbulnya ideologi atau nilai-nilai baru yang belum dimengerti oleh masyarakat ${ }^{[10]}$.

\section{Simpulan}

Sebagian besar resep telah memenuhi kriteria legalitas dan kelengkapan administratif resep sebagaimana termuat dalam Peraturan Menteri Kesehatan Republik Indonesia Nomor 72 Tahun 2016 Tentang Standar Pelayanan Kefarmasian di Rumah Sakit.

\section{Pustaka}

[1] Jas, A., 2009. Perihal Resep \& Dosis serta Latihan Menulis Resep. Ed 2.: Universitas Sumatera Utara Press, Medan.

[2] Siti Ulfa Bilqis, 2015. Kajian Administrasi, Farmasetik dan Klinis Resep Pasien Rawat Jalan di Rumkital DR. Mintohardjo. Fakultas Kedokteran dan Ilmu Kesehatan Program Studi Farmasi : Jakarta.

[3] Siti Ulfa Bilqis, 2015. Kajian Administrasi, Farmasetik dan Klinis Resep Pasien Rawat Jalan di Rumkital DR. Mintohardjo. Fakultas Kedokteran dan Ilmu Kesehatan Program Studi 
Farmasi : Jakarta.

[4] Lexy J. Meleong. 2012. Metode Penelitian Kualitatif. Bandung : Remaja Rosdakarya, 2016.

[5] Hanari Fajarini, Implementasi Peraturan Menteri Kesehatan RI No. 73 tahun 2016 Tentang Standar Pelayanan Kefarmasian di Apotek, Jurnal Para Pemikir, Volume 7, Nomor 2, Juni 2016.

[6] Sukmadinata, N S, 2011. Metode Penelitian Pendidikan. Bandung : Remaja Rosdakarya

[7] Siregar, Charles. 2006. Farmasi Klinik, Teori dan Penerapan. Jakarta.

[8] Endang Sutrisno dan Hanari Fajarini, Legal Culture Of Pharmacist In The Perspective Of Pharmaceutical Services Standard In Pharmacies, Jurnal Dinamika Hukum, Volume 16, Nomor 2, September 2016,page.151.

[9] Endang Sutrisno, "Role of law in construction and development of small scale industries through normative perspective”, Jurnal Dinamika Hukum Fakultas Hukum Universitasw Jenderal Soedirman, Purwokerto, Volume 15, Nomor 3, September 2015,page.319.

[10] Warassih, Esmi, 2014, Pranata Hukum Sebuah Telaah Sosiologis, Suryandaru Utama, Semarang, hlm.20. 